PNL-2515

UC-60

\title{
Remote Wind Measurements with a New Microprocessor- Based Accumulator Device
}

by

M. Gary Verholek

Philip A. Ekstrom

\section{April 1978}

Pacific Northwest Laboratory

Richland, Washington 99352

Operated for the

U.S. Department of Energy

by 


\title{
NOTICE
}

This report was prepared as an account of work sponsored by the United States Government. Neither the United States nor the Department of Energy, nor any of their employees, nor any of their contractors, subcontractors, or their employees, makes any warranty, express or implied, or assumes any legal liability or responsibility for the accuracy, completeness or usefulness of any information, apparatus, product or process disclosed, or represents that its use would not infringe privately owned rights.

The views, opinions and conclusions contained in this report are those of the contractor and do not necessarily represent those of the United States Government or the United States Department of Energy.

\author{
PACIFIC NORTHW'EST LABORATORY \\ sperated by \\ BATTELLE \\ for the \\ UNITED STATES DEP.ARTMENT OF ENERGY \\ Under Contract EY-76-C-06-1830
}

\begin{tabular}{|c|c|c|}
\hline \multicolumn{3}{|c|}{$\begin{array}{l}\text { Printed in the United States of America } \\
\text { Available from } \\
\text { National Technical Iniormation Service } \\
\text { United States Deparmment of Commerce } \\
5285 \text { Pon Royal Road } \\
\text { Springfield, Vinginia } 22151\end{array}$} \\
\hline Price: & Printed Copy & 2___; Microtiche $\$ 3.00$ \\
\hline & "Pages & $\begin{array}{c}\text { NTIS } \\
\text { Selling Price }\end{array}$ \\
\hline & $001-025$ & 54.50 \\
\hline & $026-050$ & $\$ 5.00$ \\
\hline & $051-075$ & $\$ 5.50$ \\
\hline & $076-100$ & $\$ 6.00$ \\
\hline & $101-125$ & $\$ 6.50$ \\
\hline & $126-150$ & $\$ 7.00$ \\
\hline & $151-175$ & $\$ 7.75$ \\
\hline & $176-200$ & 58.50 \\
\hline & $201-225$ & 58.75 \\
\hline & $226-250$ & $\$ 9.00$ \\
\hline & $251-275$ & $\$ 10.00$ \\
\hline & $276-300$ & $\$ 10.25$ \\
\hline
\end{tabular}


REMOTE WIND MEASUREMENTS WITH A NEW MICROPROCESSOR-BASED ACCUMULATOR DEVICE

by

M. Gary Verholek

Philip A. Ekstrom

April 1978

PACIFIC NORTHWEST LABORATORY Richland, Washington 99352 Operated by BATTELLE MEMORIAL INSTITUTE 



\section{CONTENTS}

1. INTRODUCTION. • . . . . . . . . . . . . . . . . . I 1

2. THE DESIGN CONCEPT. . . . . . . . . . . . . . . . 1

3. APPLICATION TO WIND ENERGY. . . . . . . . . . . . 4

3.1 oвJECTIVES . . . . . . . . . . . . . . . . 4

3.2 DATA REQUIREMENTS. • . . . . . . . . . . . . 5

3.2.1 Joint Frequency Distributions . . . . 5

3.2.2 Wind Power Estimates from wind

Speed Distributions . . . . . . . 6

3.2.3 Seasonal and Diurnal Variations . . . 9

3. 3 DATA MANAGEMENT. . . . . . . . . . . . . 10

3.4 THE SENSORS. . . . . . . . . . . . . . . . 12

3.5 INSTRUMENT DEPLOYMENT. • . . . . . . . . . . 13

3.6 QUALITY ASSURANCE PROGRAM. . . . . . . . . . 13

4. CONCLUSION. • . . . . . . . . . . . . . . . 15

5. REFERENCES. . . . . . . . . . . . . . . 16 


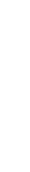




\section{REMOTE WIND MEASUREMENTS WITH A NEW MICROPROCESSOR-BASED ACCUMULATOR DEVICE}

M. Gary Verholek

Philip E. Ekstrom

\section{INTRODUCTION}

This paper describes the employment of a unique microprocessor-based accumulator device for remote meteorological measurements. The unit was designed for remote application with wind instruments to respond to the need for a very inexpensive survey unit to provide statistical summaries of basic wind data for the wind turbine siting decision process. While it is versatile enough to be used in many other remote measurement scenarios, the device will be described primarily in its application to wind measurements for siting wind energy conversion systems (WECS), otherwise known as wind turbines.

\section{THE DESIGN CONCEPT}

The device described in this paper was designed in response to recent expressions of need for a wind instrument that would be: 1) inexpensive, 2) simple, 3) rugged, 4) portable, and 5) battery-powered for extended field use. Upon examination of the type of information currently used in the early phases of WECS siting, it was noted that onsite serial meteorological data were ultimately reduced to statistical summaries. A microprocessor-based device was conceived that would allow the necessary summaries to be processed directly and stored in compact form. 
A versatile instrument was devised for in situ processing of continuous data samples from standard meteorological sensors. Though the device can be used with other sensors, such as temperature and insolation, its primary application to wind energy will be examined here.

A broad spectrum of wind instruments, based upon multiple accumulations implemented either by hardware logic or by a microprocessor, can be economically fabricated from existing components. With such instruments the wind would be observed at a fixed-time interval (such as every two minutes), classified as to state (e.g., speed between 4 and $6 \mathrm{~m} / \mathrm{s}$ ), and a count kept of the frequency of occurrence of each state. When the states considered are speed intervals, the result is a histogram representing an observed wind speed frequency distribution. Such an experimentally determined distribution can be used directly in Equation 3.2-3 to estimate how much total energy a given WECS could have generated at that site during that month. If the speed classes are few and cover a broad range, then some sort of data interpolation is necessary, particularly if the breakpoints in the wecs characteristics (cut-in, rated, and cut-out) do not coincide with class boundaries.

A joint frequency distribution results when the wind classes are compounded of speed and direction (e.g., between 4 and $6 \mathrm{~m} / \mathrm{s}$ out of the Northwest). It may be considered as either a wind rose for each speed interval or a frequency distribution for each direction. Such data can be used for the initial characterization of wind behavior at the site.

Diurnal variations in power availability are obtained when the classes are compounded of speed and time of day (e.g., between 4 and $6 \mathrm{~m} / \mathrm{s}$, and between midnight and $3 \mathrm{a.m.)}$. Power availability can then be compared to the diurnal power demand of the intended load. 
A number of manufacturers presently offer multiple accumulators which, with minor modification, could provide such information. A simple instrument has been constructed which samples uniformly with respect to wind run instead of time. 1 However, none of them seem to be suited for general prospecting use. There are units now manufactured which can produce joint frequency distributions or which with modification could produce diurnal distributions, but no single unit does both. Such instruments are expensive and most are too bulky, heavy, and/or power consuming to allow backpacking the units into a remote area.

Having considered a number of possible designs incorporating combinations of various features, it was determined that a microprocessor-based device offers by far the greatest flexibility and least complexity. Its cost and power drain are comparable with that of the other options employing hardwired logic. The complexity of keeping a given statistic is embodied in the program, not in wires and gates. Information is accumulated under program control, which would be prohibitively costly to wire.

Since memory devices dominate the cost of the units, the design can be arranged to allow less expensive, stripped-down versions, which would provide only basic statistics for wind prospecting.

The general prospecting device would have microprocessor capability and sufficient memory to obtain a joint frequency distribution and a diurnal distribution, as well as run duration and turbulence distributions. The microprocessor could be programmed to provide many such statistics. By deleting some memory devices, one could reduce the cost of the units; the memory chips can be added later if the need arises for the original capability. In a prospecting program where cost is more critical than the additional information, such instrument 
flexibility is highly desirable. In many cases, a single ful1-dressed version could be used with several stripped-down versions to provide adequate instrumentation for prospecting.

Such systems would be inexpensive, yet would provide all the prospecting data required for site localization and even much of the data required for detailed evaluation of a prospective WECS site.

Details of the design of such an instrument have been described by Ekstrom and Verholek ${ }^{2}$, and are the basis for the ensuing discussion.

\section{APPLICATION TO WIND ENERGY}

\subsection{OBJECTIVES}

The objectives of wind prospecting measurements are twofold: first, to localize areas of high wind energy potential, and secondly, to estimate that potential. The second does not necessarily have to be preceded by the first. When a user has only one site available for a WECS and wishes to ascertain the wind energy potential before resorting to the expense of a detailed analysis, this instrument can inexpensively provide the information. When a potential user has a large land area and wishes to place his WECS units to provide the maximum return on his investment, the user would like to make measurements at several locations on the prospective site with inexpensive instruments to ascertain the potential. This instrument is ideally suited for just such an application. The ensuing discussion will address the latter situation of a large prospective area, with the situation of a single, predetermined site as the simplest case. 


\subsection{DATA REQUIREMENTS}

There are certain wind characteristics which need to be determined for WECS siting and which lend themselves to the statistical summaries readily producible on the microprocessor device. The specification of the desired information and the method of arriving at that information follow.

\subsubsection{Joint Frequency Distributions}

Local mean airflow patterns can be inferred by using joint frequency distributions of wind speed and direction. The joint frequency distributions show the predominant wind direction(s) and the associated frequency distributions of speed at each point of observation. The analysis of coincident records from several observing points coupled with an analysis of upstream conditions, such as terrain, roughness and thermal influences, can be useful for inferring the relative importance of such things as channeling and the influence of large bodies of water. This information can be helpful for deducing the general flow pattern at the site area, and inferring the location of enhanced wind speed and/or sheltered sites.

Inferences or deductions need to be verified with measurements at the prospective sites. The behavior of nearsurface winds over relatively flat ground, and the increase in speed with height, are fairly well known, but only very general information exists on airflow over complex landforms (i.e., cliffs, hills, mountains and valleys). This lack of precise information on generic airflow is a real problem when one considers that an increase in the mean velocity of $1 \mathrm{~m} / \mathrm{s}$ can result in a 50 to $95 \%$ increase in available power for mean velocities between 4 and $7 \mathrm{~m} / \mathrm{s}$, based on the Rayleigh distribution of velocity. ${ }^{3}$ 
The turbulent nature of the wind is also influenced by the upstream conditions (terrain, roughness, and thermal influences). Because these influences generally vary with direction, the nature of the airflow also varies with direction. Thus, the joint frequency distribution provides the distribution of speed and direction relative to the topography and other local influences.

\subsubsection{Wind Power Estimates from Wind Speed Distributions}

An evaluation of a potential WECS site must also provide a quantitative estimate of the power potential of the site. The available power is the equivalent of the kinetic energy of the moving mass of air and is given by

$$
\mathrm{P}=1 / 2 \cdot \mathrm{d} \cdot \mathrm{A} \cdot \mathrm{v}^{3}
$$

where

$$
\begin{aligned}
& \mathrm{P}=\text { power available from the wind } \\
& \mathrm{d}=\text { air density at the site } \\
& \mathrm{A}=\text { area swept out by the blades } \\
& \mathrm{V}=\text { wind speed at the machine hub height. }
\end{aligned}
$$

Then the average power available at the site is

$$
\overline{\mathrm{P}}=\int_{0}^{\infty} \mathrm{P}(\mathrm{v}) \cdot \mathrm{p}(\mathrm{v}) \cdot \mathrm{dv}
$$

where

$$
\begin{aligned}
\overline{\mathrm{P}} & =\text { the average available power } \\
\mathrm{P}(\mathrm{v}) & =\text { power available at wind speed } \mathrm{v} \\
\mathrm{p}(\mathrm{v}) & =\text { frequency of wind speed } \mathrm{v} .
\end{aligned}
$$

$P(V)$ is expressed in Eq. 3.2-1 above, and the frequency distribution of speed, $\mathrm{p}(\mathrm{v})$, is determined from measurements at a site. 
Using the available power, the prospector can determine the relative potential of the sites as part of the selection process. However, for an economic analysis, the user often wants an estimate of the extractable power. The extractable power is the power that can be produced by a given WECS and is a function of the wind characteristics, as well as the machine characteristics, such as cut-in, rated and cut-out speeds. According to $\mathrm{Cliff}^{4}$, an estimate of the turbine's expected average power output may be computed from:

$$
\overline{\mathrm{T}}_{\mathrm{p}}=\int_{0}^{\infty} \mathrm{T}_{\mathrm{p}}(\mathrm{v}) \cdot \mathrm{p}(\mathrm{v}) \mathrm{dv}
$$

where

$$
\begin{aligned}
\overline{\mathrm{T}}_{\mathrm{p}} & =\text { the average extractable power for the turbine } \\
\mathrm{T}_{\mathrm{p}}(\mathrm{v}) & =\begin{array}{l}
\text { specified turbine output as a function of } \\
\text { wind speed }
\end{array} \\
\mathrm{p}(\mathrm{v}) & =\text { frequency distribution of the wind speed } \\
\mathrm{v} & =\text { wind speed at hub height. }
\end{aligned}
$$

Figure 3.2-1 graphically describes the processes involved in Eq. 3.2-3. Figure 3.2-1(A) depicts a typical wind turbine performance curve. At a cut-in wind speed, A, the turbine begins to produce power and monotonically produces more power as the wind speed increases, until it reaches the rated wind speed, B. Above this wind speed the wind turbine's power output stays constant until the wind turbine's cut-out speed, $\mathrm{C}$, is reached. At wind speeds greater than the cut-out speed, the wind turbine does not produce power. The turbine's blades are usually feathered or are designed to stall above the cutout speed to prevent damage to the machine.

Figure 3.2-1(B) depicts a typical wind speed frequency distribution. Only a small percentage of time is spent at either the extremely low or high ends of the distribution. The 


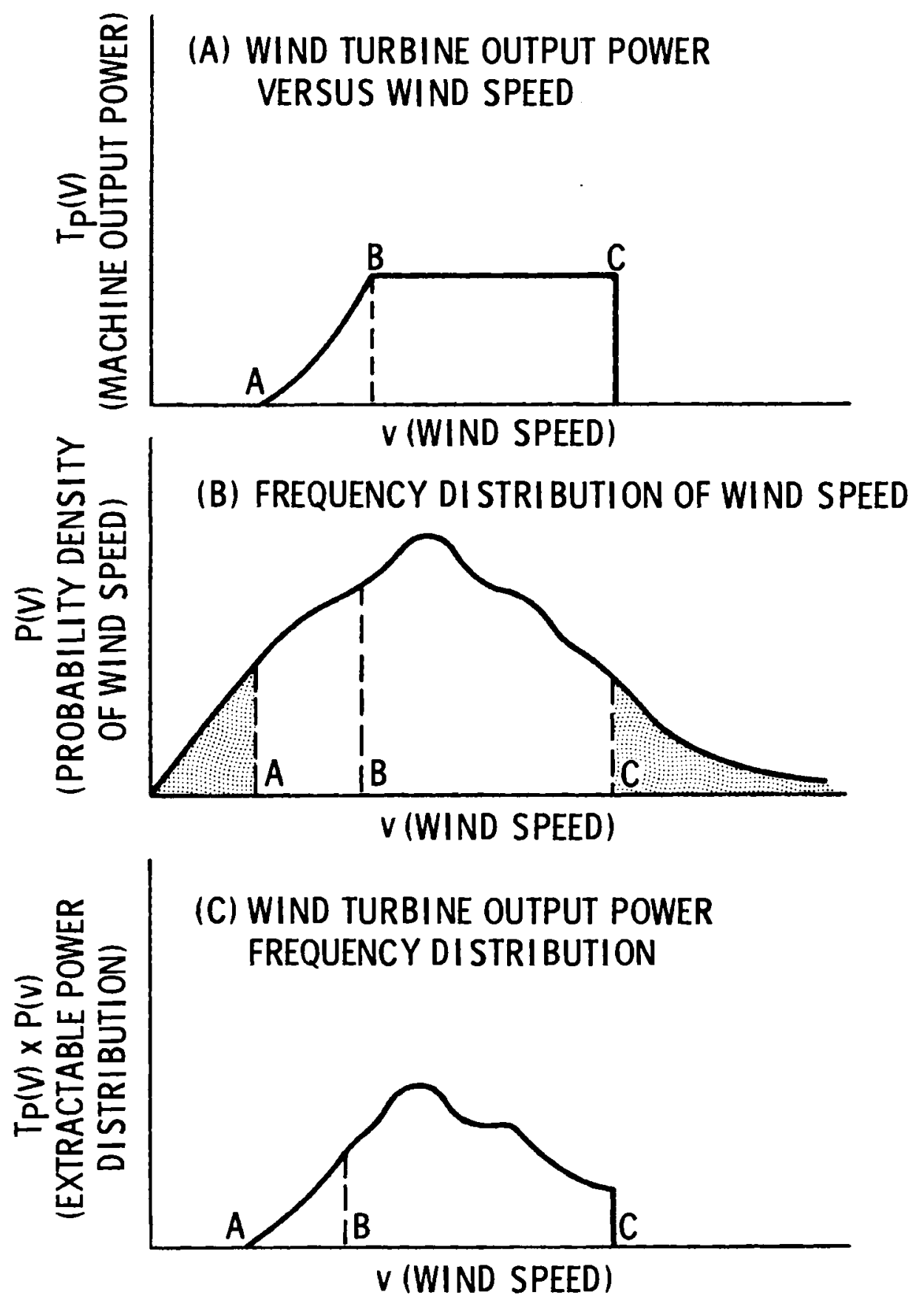

Figure 3.2-1. Interaction of Wind Turbine Characteristics and Wind Statistics to Produce the Wind Turbine Power Frequency Distribution 
convolution of the curves in Figs. 3.2-1(A) and (B), $\mathrm{T}_{\mathrm{p}}(\mathrm{v}) \mathrm{x}$ $p(v)$, yields the power frequency distribution of the wind turbine's output as a function of wind speed, Fig. 3.2-1(C). The integral of this curve (Eq. 3.2-3) then yields the average expected power output of the wind turbine, $\overline{\mathrm{T}}_{\mathrm{p}}$. Since the wind turbine only produces power when the wind speed is between the cut-in and the cut-out wind speed, the integration of Eq. 3.2-3 needs to be performed only over these limits (rather than from 0 to $\infty$ ).

The frequency distributions, generated from discrete or averaged observations and depicted as histograms of the number of observations in each speed interval and in each direction interval, can be either used directly or fitted with a distribution function for integration in closed form. The method of analysis employed will depend on the coarseness of the intervals selected. Preplanning in the measurement program should prove useful in this respect.

The result obtained by the application of Eq. 3.2-3 should provide a reasonable estimate of the average power produced by a specific wind turbine operating in an environment described by $p(v)$. Nevertheless, the actual power output of the turbine may differ from this estimate since other factors (e.g., vertical profile of the horizontal component of wind velocity, the wind direction variability and turbulence) are not accounted for in Eq. 3.2-3. These factors should be thoroughly considered in a detailed site evaluation. In the prospecting phase, however, results based on the foregoing discussion are adequate.

\subsubsection{Seasonal and Diurnal Variations}

The usability of the power from WECS also depends in some cases on matching the availability of power with the demand. This is especially true in direct applications where there is no storage and where the WECS is expected to supply a 
significant portion of the power base. But in any case, usability will be enhanced where supply matches demand. This is not trivial and should be examined as part of the installation decision process.

Data in the Wind Energy Mission Analysis Reports of Lockheed $^{6}$ and General Electric ${ }^{7}$ graphically depict the variability of both power demand and the supply of available wind energy. An examination of these documents reveals variations in the available wind energy which include:
a) seasonal variations that differ with location;
b) diurnal variations that differ with location;
c) diurnal variations that differ with the seasons at different locations.

These same reports show variations in power demand that are directly related to the application and/or primary consumer. Clearly, generalized cyclical variations in power demand are not adequate input for siting decisions.

Most load demands are sufficiently individual to warrant complete examination. Localized available power estimates, produced on a monthly and diurnal basis, need to be examined with respect to their coincidence with cyclical load demands.

\section{3 DATA MANAGEMENT}

When setting up a microprocessor-based prospecting instrument, considerable flexibility is available in the choice of data organization. In addition, choices once made may be altered by program changes. The organization presented here is an initial choice which may be modified, based upon field experience.

Statistics to be kept include a 128-class frequency table organized as 16 wind speed classes for each of eight direction 
classes. Another 128-class table accumulates 16 wind speed classes for each 3-hour period during the day. For both of these tables, the wind speed classes will consist of uniform intervals with the topmost interval open ended. No more than $5 \%$ of the counts should lie in the top interval. Based upon a Rayleigh distribution for sites with average wind speed below $15 \mathrm{~m} / \mathrm{s}$, a $2 \mathrm{~m} / \mathrm{s}$ class width appears to be adequately narrow to permit good power estimates. While this choice should be adequate for nearly any site, in cases where advance information is available on a site's average wind speed, appropriate intervals could be programmed into the microprocessor.

All class counters have a capacity of $2^{16}$ counts, or one per minute for about 40 days. Data will be taken every two minutes, either instantaneously or averaged, by counting anemometer pulses. As each wind speed count is completed, it will be used to update a peak wind speed cell before being classified.

To recover the prospecting unit's data will require a readout module carried to the site. The simplest device is a standard battery-powered audio cassette tape recorder employing the "Kansas City standard" recording format popular with computer hobbyists. Such a readout unit is inexpensive enough to be left with a local resident hired to read out and reset the prospecting unit each month, and mail in the resulting tape. Arrangements of this sort are presently in successful operation within other PNI projects. This method of data recovery does require a facility to read the tapes produced.

A stand-alone $\mathrm{RS}-232-\mathrm{C}$ compatible readout unit based upon a miniature printer would produce a printed summary directly. The output would be in decimal form and organized as histograms, which are the frequency distributions expressed directly in minutes of occurrence per month. 


\subsection{THE SENSORS}

The wind speed (WS) and direction (WD) sensors can be any of a great variety of commercially available makes and models. The WS sensors can be the generator type, the single pulse contact or reed switch type, or a low-power lightchopper type device. The WD sensor can be either an eightposition vane or a potentiometer-type vane. Inexpensive sensors with reasonable accuracy $( \pm 5 \%)$ and characteristics $(2-4 \mathrm{~m}$ distance constant, and 0.5-1 damping ratio) are all that are required in the prospecting phase. To be compatible with the remote mission of the system, the sensors should be of very low power drain and high reliability. Such instruments are readily available from any scientific instrument company.

Sensors should be set at $10 \mathrm{~m}$ above the roughness element, in locations which provide an unobstructed flow to the sensors. In heavy vegetation, such as forested areas, the sensors should be located $10 \mathrm{~m}$ above the canopy. Similarly, where buildings or other obstructions would interfere with the flow, the sensors should be elevated approximately $10 \mathrm{~m}$ into the free air. Any convenient location can be used for the sensor stand: towers, poles, trees (stripped), etc. The sensor must be free of movement and exposed to the unobstructed flow of the air.

The sensors should be mounted at least $2 \mathrm{~m}$ into the prevailing wind on the upwind side of any existing open lattice towers. Solid structures should be avoided, but in the event water towers, forestry service towers, or similar structures are being considered, the sensors should be placed five to eight times the largest dimension above the structure. It is imperative that the sensors be properly placed to sample the unobstructed flow of the free air. 


\subsection{INSTRUMENT DEPLOYMENT}

Since the objectives of prospecting are: a) to identify local areas of high winds, and b) to estimate the wind energy potential there, the instruments should be strategically deployed and repositioned as necessary so that they will provide representative data for the siting decision process. Using various techniques described in any of several WECS siting handbooks ${ }^{7-11}$, likely areas of high winds should be identified as a first estimate, and preliminary sites selected on the basis of existing information. Ideally, one would like to dot a prospective site area with anemometers, putting one anywhere which seems promising. This is obviously costly, so one should begin with a thorough analysis of the terrain influences and the predominant flow, place a few instruments to verify the initial information (1-2 months), then place instruments on what appears to be the best sites in the area. Since this is a survey for the best WECS sites, a reconfiguration of the instruments is not unlikely, adding or moving instruments to the most promising sites.

\subsection{QUALITY ASSURANCE PROGRAM}

The entire program should be managed with a great deal of attention given to quality assurance:

1) Matched instruments should be acquired from a reputable firm, calibrated annually, and field-tested quarterly.

2) A log book should be kept on each site. The log book shall contain detailed records of installation, maintenance visits, problems and actions. All relevant information should be regularly entered in the $\log$ book. 
3) The same sensors and procedures should be used with each unit operating in a localized area. Thus intercomparisons will not be hampered by dissimilar instrument characteristics.

The use of inexpensive equipment should not be grounds for poor quality assurance. The systems will serve well if the project is conducted well.

Calibration and quality assurance should present no special problems, even when the unit is tended by a local resident. The prospecting units are to be as rugged and longlived as possible. All of its electrical measurements are relative values except when employing a generator-type anemometer, so in most cases only the wind instruments themselves need be calibrated. The techniques used for timekeeping and for subroutine linkage will constitute stringent checks on the integrity of the processor, and each data reset operation will incorporate a memory test. Data on tape will be triply redundant, and printed output can be accompanied by a check sum of the total number of occurrences. In addition, the entries in each of the separate distribution tables must sum to the number of minutes which have elapsed since the last reset, allowing a further test of processor, memory, and data transmission integrity. Each data output will include the serial number of the unit, and the program revision number, allowing positive identification of the data independent of the readout operator's notes.

The entire prospecting system should be calibrated at least every four months. Ordinary good practice in handing prospecting unit readout should suffice for all quality assurance matters between recalibrations. 


\section{CONCLUSION}

Wind measurements using microprocessor-based instruments are an inexpensive way to obtain statistical summaries of basic wind data for the wind turbine siting decision process. The measurements provide data for statistical summaries of:

- joint frequency distributions of speed and direction,

- wind power estimates,

- seasonal and diurnal variations,

- turbulence characteristics (optional),

- run duration or persistence (optional).

The instrument has the desirable qualities of being:

- inexpensive

- simple

- versatile

- rugged

- portable. 


\section{REFERENCES}

1. Fowler, W. B., "Versatile wind Analyser for Long Unattended Runs Using C-MOS," Journal of Physics E: Scientific Instruments 8, pp. 713-14 (1975). AIso see U.S. Patent 4,011,752.

2. Ekstrom, P. E. and Verholek, M. G., A Wind Prospector's Instrument, PNL-25I4, Battelle, Pacific Northwest

Laboratories, Richland, WA 99352, April 1978.

3. Elliott, D. L., Synthesis of National Wind Energy Assessments, BNWL-2220, WIND-5, Battelle, Pacific Northwest Laboratories, Richland, WA 99352, July 1977.

4. Cliff, W. C., The Effect of Generalized wind Characteristics on Annual Power Estimates from Wind Turbine Generators, PNL-2436, Battelle, Pacific Northwest Laboratories, Richland, WA 99352, October 1977.

5. Wind Energy Mission Analysis, SAN/1075, LockheedCalifornia Company, Burbank, CA 91520, September 1976.

6. Wind Energy Mission Analysis, Coo/2578, General Electric Company, Philadelphia, PA 19101, February 1977.

7. Eldridge, F. R., Wind Machines, NSF-RA-N-75-051, NSF Report, prepared by Mitre Corp., Available from NTIS, Springfield, VA 2215l, 76 pp., 1975.

8. Wegley, H. L., A Siting Handbook for Small Energy Conversion Systems, PNL-2521, Battelle, Pacific Northwest Laboratories, Richland, WA 99352, January 1978 (Draft Report).

9. Park, J. and Schwind, D., Wind Power for Farms, Homes, and Small Industry, prepared for the Energy Research and Development Administration by Nielsen Engineering and Research, Inc., Mountain View, CA 94043, September 1977.

10. Frost, W. and Nowak, D., Handbook of Wind Turbine Generator Siting Techniques Relative to Two-Dimensional Terrain Features, RLO/2443-77/1, prepared for Battelle, Pacific Northwest Laboratories by FWG Associates, Inc., Tullahoma, TN 37388, April 1978. 
11. Survey of Historical and Current Site Selection Techniques for the placement of Small wind Energy Conversion Systems, BNWL-2220 WIND-9, American Wind Energy Association, c/o Windworks, Mukwonago, WI 53149, prepared for Battelle, Pacific Northwest Laboratories, Richland, WA 99352, December 1977. 


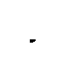


PNL

Report No: PNL-2515

Date: April 1978

\section{PNL DISTRIBUTION}

No. of

Copies

OFFSITE

A. A. Churm

DOE Chicago Patent Group

9800 South Cass Avenue

Argonne, IL 60439

G. P. Tennyson

Department of Energy

600 E Street, N. W.

Washington, DC 20545

\section{DOE Technical Information Center}

Thomas Vonier

AWEA Windletter

2222 Q Street, N.W.

Washington, DC 20008

Dr. Paul B. MacCready, Jr.

AeroVironment, Inc.

145 Vista Avenue

Pasadena, CA 91107

Clarissa Quinlan

Alaska State Energy Office

338 Denali Street

Anchorage, AK 99501

Paul N. Vosburgh

Alcoa Allied Products

Aluminum Company of America

Alcoa Center, PA 15069

Dr. K. C. Spengler

American Meteorological Society

45 Beacon Street

Boston, MA 02108

Ben Wolff

American Wind Energy Association

c/o Windworks

P. 0. Box 448, Route 3

Mukwonago, WI 53149
No. of

Copies

Richard Katzenberg

American Wind Energy Association

Natural Power, Inc.

New Boston, NH 03070

E. J. Warchol

Bonneville Power Administration

P. 0. Box 3621

Portland, OR 97225

S. J. Hightower

Bureau of Reclamation

Denver Federal Center

B1dg. 67, Code 254

Denver, CO 80225

M. Ginosar

California Solar Energy Commission

Energy Resources, Conservation and Development Commission

1111 Howe Avenue, Mail Stop 15

Sacramento, CA 95825

Robert Ball

Center for the Environment and

Man, Inc.

275 Windsor Street

Hartford, CT 06120

Dr. R. J. Hawks

Clarkson Cohlege

Potsdam, NY 13676

Dr. R. N. Meroney

Colorado State University

Fort Collins, CO 80523

E. H. Gilmore

Department of Agriculture

Agriculture Research Service

Bushland, TX 79012 
No. of

Copies

L. A. Li ijedah 1

Department of Agriculture

Agriculture Wind Energy Program

Building 001 , Room 126 BARC-West

Beltsville, MD 20705

Douglas G. Fox

Department of Agriculture

Forest and Mountain Meteorology

Rocky Mountain Forest and Range

Experiment Station

240 West Prospect Street

Fort Collins, CO 80521

Major T. E. Kullgran

Department of the Air Force

USAF Academy, CO 80840

Jay Tappan

Department of Energy

State of Oregon

Labor and Industries Building

Room 111

Salem, OR 97310

Harry Moses

Department of Energy

Division of Biomedical and

Environmental Research

Mail Stop E-201

Washington, DC 20545

Dr. 01 le Ljungstrom

FFA, The Aeronautical Research Institute

Forskningsstationen i Stockholm

Drottning Kristinas Vag 47

S-11428 Stockholm, Sweden

Carl Miner TAN-604

EG\&G Idaho, Inc.

P. 0. Box 1625

Idaho Falls, ID 83401

Dr. Edgar Demeo

Electric Power Research Institute 3412 Hillview Avenue

Palo Alto, CA 94303
No. of

Copies

Jim Lerner

Energy Resources Conservation and Development Commission

California Solar Energy Office

Mail Stop 15

Sacramento, CA 95825

Dr. W. Frost

FWG Associates, Inc.

R. R. 3, Box 331

Tullahoma, TN 37388

L. Krawitz

General Electric Company

P. 0. Box 8555

Philadelphia, PA 19101

R. C. Koch

Geomet, Inc.

15 Firstfield Road

Gaithersburg, MD 20760

C. G. Justus

Georgia Institute of Technology

Atlanta, GA 30332

Darryl Tompkins

JBF Scientific Corporation

1925 North Lynn Street

Suite 308

Arlington, VA 22209

Dr. J. B. Knox

Lawrence Livermore Laboratory

University of California

P. 0. Box 808

Livermore, CA 94550

Ms. Abbey Page

Maine Office of Energy Resources

55 Capitol

Augusta, ME 04330

S. M. Howard

Meteorology Research, Inc.

P. 0. Box 637

Altadena, CA 91001 
Phillip French

NASA Scientific and Technical Information Facility

P. 0. Box 8757

Baltimore/Washington International Airport

MD 21240

\section{R. A. Wolf}

NASA/Lewis Research Center

Mail Stop 500-201

Cleveland, $\mathrm{OH} \quad 44135$

M. J. Changery

National Oceanic and Atmospheric Administration

National Climatic Center

Federal Building

Asheville, NC 28801

R. J. Templin

National Research Council of Canada National Aeronautical Establishment M-2 Montreal Road

Ottawa, Ontario KIA OR 6

Ms. Peggy McDonald

N. E. Solar Energy Center

70 Memorial Drive

Cambridge, MA 02142

M. W. Edelstein

North American Weather Consultants 600 Norman Firestone Road

Goleta, CA 93017

R. B. Corotis

Northwestern University

Evanston, IL 60201

E. W. Hewson

Oregon State University

Corvallis, OR 97331

S. C. Crow

Poseidon Research

11777 San Vicente Boulevard

Suite 641

Los Angeles, CA 90049
Dr. F. M. Vukovich

Research Triangle Institute

P. 0. Box 12194

Research Triangle Park, NC 27709

Terry J. Healy

Rockwell International

Rocky Flats Plant

P. 0. Box 464

Golden, CO 80401

2 R. E. Akins/J. W. Reed

Sandia Laboratories

Division 5443

P. 0. Box 5800

Albuquerque, NM 87115

R. M. Traci

Science Applications, Inc.

P. 0. Box 2351

La Jolla, CA 92038

D. M. Hardy

Solar Energy Research Institute

1536 Cole Boulevard

Golden, C0 80401

Dr. C. M. Bhumralkar

Stanford Research

Institute, International

Men 10 Park, CA 94025

Dr. T. Wentink, Jr.

University of Alaska

Fairbanks, AK 99701

Dr. P. Yuen

University of Hawai $i$ at Manoa

Holmes Hall 240

2540 Dole Street

Honolulu, HI 96822

C. E. Duchon

University of Okalahoma

200 Felgar Street

Norman, OK 73069 
No. of

Copies

Dr. N. K. Wagner

University of Texas

Austin, TX 78712

Dr. M. Garstang

University of Virginia

Charlottesville, VA 22903

Dr. R. W. Marrs

University of Wyoming

Laramie, WY 82071

David Kapus

Washington State Division of

Engineering and Architecture 106 Maple Park Drive

O1ympia, WA 98504

Ms. Susan Hosch

Washington State Energy Office 400 E. Union Avenue, lst Floor

01 ympia, WA 98504

Prof. Kent Rowe

Wichita State University

Box 444

Wichita, KS 67208
No. of

Copies

ONSITE

2 DOE Richland Operations Office

G. L. Liffick

H. E. Ransom

54 Battelle-Northwest

W. C. Cliff

R. L. Conley

J. C. Doran

R. L. Drake

P. A. Ekstrom (5)

C. E. Elderkin

R. K. Hadlock

M. M. Orgill

W. T. Pennell

E. H. Phinney

J. V. Ramsdel1

D. S. Renne

C. L. Simpson

M. G. Verholek (5)

L. L. Wendel 1

Technical Information (5)

Technical Publications 